\title{
Weekends at Ayot
}

\author{
LILLAH McCARTHY
}

From Lillah McCarthy, Myself and My Friends (London: Butterworth, 1933) p. 86. Lillah visited the Shaws at Ayot St Lawrence during rehearsals for The Doctor's Dilemma, in which she played Jennifer Dubedat, with Granville Barker as Dubedat, and which opened on 20 November 1906 at the Court Theatre.

I have often been asked by people who admire or who dislike Shaw to give them a picture of Bernard Shaw at home. The admirers are pleased and the hostile disappointed to see what a charming picture it is. It began to paint itself in my mind during the fine weekends of 1906 when I used to stay with Mr and Mrs Shaw at Ayot. They were weekends of rest and quiet. Shaw would run round the garden in the morning, doing his breathing exercises the while. After breakfast we would walk, and sometimes we would carry on our conversation with quotations from Shakespeare or Dickens. His memory was amazing and mine was not so ill, so we enjoyed ourselves and fed a harmless vanity at the same time. In the afternoon, he would play his pianola or read a book. There were no hectic discussions and no displays of cleverness. Sometimes there might be leisurely talks about our friends, the Sidney Webbs, of the work of the Fabian Society, or of the vagaries of the new member, H. G. Wells.

\section{'Squire' Shaw}

\author{
FRANCIS HOPKINS
}

From Francis Hopkins, "Squire" Shaw: Being an Unconventional Interview with one of the Most Written-about Persons in the Public Eye', Lady's Realm, October 1909.

Everybody in Ayot St Lawrence knows Mr Shaw as the village squire, and as none other. The working-man villagers raise their hats as he 